original article

\title{
Ideological Consistency and Ideological War: American Fascism vs Antifascism - January 2021
}

Joel Ivan Gonzalez Cedillo

St. Petersburg State University, Russia, St. Petersburg

ivangzz.ced@gmail.com

http://orcid.org/0000-0001-8040-749X

Received 4 Feb 2021. Accepted 5 Mar 2021.

Abstract: This work analyzes the ideological war between American fascists and antifascists and the relation between the existence of an ideological consistency among the masses and the emergence of this type of conflict. The storming of the US Capitol in January 2021 by fascists and the activities of fascists and antifascists on social media serve as subjects for the analysis of this ideological war. The purpose of this work is to study literature on ideological wars and analyze how States encourage extremist ideologies based on their own ideological consistencies. The method employed to expose the ideological war is a content analysis of social media used by the Proud Boys and Atlanta Antifascists. The results show that the two competing ideologies cannot coexist peacefully in the same territory and at the same time. The State and the elites agree that the confrontation should end. This work can be useful for academics, policy makers and students working on the issue of fascist and extremist ideologies, as well as for developing ways to fight these ideologies by addressing their enablers.

Keywords: American fascism, antifascism, white supremacy, ideology, extremism

Citation: Gonzalez Cedillo J. I. Ideological Consistency and Ideological War: American Fascism vs Antifascism - January 2021. Vestnik Kemerovskogo gosudarstvennogo universiteta. Seriia: Politicheskie, sotsiologicheskie i ekonomicheskie nauki, 2021, 6(1): 10-18. DOI: https://doi.org/10.21603/2500-3372-2021-6-1-10-18

\section{Introduction}

Far-right political parties in the European Union have been in the political scene since the early 2000, starting before the Donald Trump phenomenon of 2015 [1]. Back in the day, the European far-right focused on reducing immigration and opposing further integration of EU institutions, as well as the adoption of a EU constitution. These political forces were outcasts and their xenophobic discourse was hardly accepted in public until the economic crisis of 2008, the migrant crisis of 2015, the presidential campaign of D. Trump and his eventual victory changed that and normalized their fascist ethnonationalist and authoritarian political ideology in Europe and North America. This ideology was met with resistance by the opposing movement of antifascism, especially in the US. This confrontation led to an ideological war between fascists and antifascists that we saw in the period of 2015-2021 on the streets of many European and American cities and also online, on social media platforms like Twitter. Although this is a Euro-American phenomenon, this work is focused on the American issue for its cultural and political impact on the spread of such ideologies in the West.

To explore the relation between ideology and sociopolitical conflicts, I started with a hypothesis that an ideological war is enabled by the existence of groups of people with very defined ideological consistencies, unwilling to recognize the existence of other Truths. This work will try to answer the question: Can different Truths coexist in the same society? To elaborate on this question,
I explored the characteristics of fascism and anti-fascist movement in the US. To exemplify this ideological war, I focused on the ideologies of the two groups by analyzing the posts in their social media accounts from January 6th to January 20th, 2021: the Proud Boys on Telegram and Atlanta Antifascists on Twitter. I chose this period as January 20th was the date when the president of the US changed and January 6th was when far-right extremists stormed the Capitol in Washington, inspired by the claim of D. Trump that the election he lost was rigged.

Media have a capability of spreading the ideas of extremist and terrorist groups through the unintentional circulation of journalist reports on those groups, which influences the actions that the audience may take against the perceived enemy [2, p. 341, 342]. Social media, being independent from mass media, help disseminate information more democratically avoiding the elitist control of the resourceful bourgeoisie; however, they require more efforts to moderate extremist content [3, p. 116]. In this regard, the role of social media in this ideological war is unquestionable: platforms like Facebook, Twitter, YouTube, Telegram and Parler have allowed the circulation of extremist political ideas almost uncensored in the U.S. Of all of them, Twitter seems an ideal platform as it allows sharing content quicker and to a broader audience. Posting opinions and gaining popularity on Facebook is limited to groups and contacts, YouTube is not very interactive for real time and durable political discussions, Telegram is not popular in the U.S. 
and Parler is limited to far-right circles. Parler was also recently blocked and is not ideologically diverse for research on the proposed ideological war. Some of these platforms have started blocking extremist content but this has only made fascist users migrate to other platforms like TikTok recently [4, p. 123, 124].

Though fascists and antifascists use social media to spread their ideologies, it is the adherents of fascism that have been observed to use these tools to spread hate and target ideological enemies [5, p. 45-47]. While fascists use these platforms to instigate violence against traditionally oppressed groups, antifascists use them to spread propaganda against these aggressors ${ }^{1}$. Previous research using Twitter as a source of data has demonstrated how this platform can be used to polarize society through strategies like the use of hashtags [6], or how influential leaders of the far-right can successfully engage followers through the use of an 'us vs them' narrative, an affective language and the expression of negative emotions [7]. Twitter also serves as a tool for influential leaders of the far-right to mobilize voters and orientate the political debate as they wish [8, p. 228-230].

The possibilities of using social media to analyze content posted by fascist and antifascist groups allows gathering data that helps to understand the main propositions of these ideologies and how these ideological groups perceive each other. This allows us to understand where the moments of confrontation arise, how popular these ideologies are among the public and what direction the political discourse might take in order to commit to the instrumental ideological consistency of potential voters. Among the limitations of using content analysis of posts from Twitter and Telegram are censorship, or deletion of posts, and blocking of accounts due to the infringement of rules of usage, which affects the continuity of messages and ideas. Also, Twitter allows writing only 280 characters, which together with the use of emojis, memes and photos can affect the result of automated content analysis. This can also be inconvenient for those researchers who are not familiar with cultural specifics of online language used by American fascist and antifascist groups.

\section{Typology of political ideologies}

In the political and religious fields, extremism can be understood as the imposition of the individual Truth on others, with the Truth being the result of the continuous consumption of an artificial ideology that makes individuals believe their perception of reality is the only valid and others can be ignored and eliminated $[9$, p. 6]. Based on the analysis of different academic materials, I have defined ideology as a set of ideas that can be constructed in the minds of individuals either naturally, through a process of enculturation, or artificially, through the psychological discursive practice.
This set of ideas is not limited to cognitive concepts as it also includes emotions necessary to give such concepts a meaning. The aim of natural ideology is to provide individuals with cognitive means to understand and transform their reality, while the aim of artificial ideology is to achieve gains (political, economic, social, etc.) that serve the interests of an elite. In this regard, the psychological discursive practice of artificial ideology can present a distorted representation of reality to create a false consciousness [9, p. 6].

Ideology can be of two types: 1) natural or positive if it is transmitted in a circular process of social interaction among equals free from the influence of privileged individuals trying to manipulate or control them;2) artificial or negative if it is transmitted in a linear discursive process from top to bottom where resourceful elites create the discourse they want the dominated masses to accept $[9, \mathrm{p} .6]$.

The constant consumption of an artificial or negative ideology will create an ideological consistency in individuals that will block their view of other Truths. J. Barcelo proposes that ideological consistency can be of two types: 1) instrumental, depending on its origin; and 2) dominance, depending on its function [10]. The instrumental ideological consistency is used by the masses to control political elites and make them commit to the interests of the electorate [10]. This is done by identifying what ideologies the political elites propose and then using the individuals' votes in democracy to threaten the political elites if they do not commit to the interests of the ideologized and informed masses. The dominance type occurs when the political elites are able to dictate the ideology the masses will adhere to. This happens when the masses have little political information and a low ideological consistency, and so are easily manipulated [10]. The instrumental type proposes a bottom to top transmission of ideology while the dominance type, from top to bottom. This work focuses on the dominance type of ideological consistency that is spread by ideologues of an artificial ideology from top to bottom among the masses to modify their behavior and make them join their fascist groups or antifascist movement.

A top to bottom ideological consistency created by a political elite will form the mentioned Truth in the receptive individuals and make them believe their Truth is the only valid and any other invalid Truth must be eliminated. From this confrontation of ideological consistencies emerge ideological wars, like we have seen between Capitalism and Communism in the years of the Cold War or more recently between Fascist and Antifascist activists and the masses, especially after 2015 .

The term 'ideological war' has not been used to describe this confrontation of ideologies; it has rather been called the 'information war'. L. N. Kunakova defines an information war from a psychological perspective as "the latent influence

\footnotetext{
${ }^{1}$ Jones S. G., Doxsee C., Harrington N., Hwang G., Suber J. The war comes home: the evolution of domestic terrorism in the United States. CSIS. 22 Oct 2020. Available at: https://www.csis.org/analysis/war-comes-home-evolution-domestic-terrorism-united-states (accessed 10 Dec 2020 ).
} 
of information on individual, group and mass consciousness using methods of propaganda, disinformation, manipulation" $[11$, p. 93]. Its goal is "to form new views on the sociopolitical organization of society through a change in value orientations and basic attitudes of the individual" [11, p. 93]. Other researchers, for example, C. Abdyraeva, consider an information war (warfare) to be part of a hybrid war aiming at influencing "people's perceptions, belief systems and emotions" with the intention "to spread misleading information", for which conspiracy theories and fake news can be used to manipulate public opinion [12, p. 20-28]. For M. P. Yaroshenko, extremism is used as a tool in a hybrid war to achieve certain goals through an information war, the latter being part of the former [13, p. 54]. This information war aims at creating confrontations between the leading political forces, igniting nationalism, racism, xenophobia and hatred towards religious groups, as well as calling for social disorder and protests, among other manifestations $[13$, p. 55]. The polarity theory can also help us understand the ideological war: "ideological thought is structured universally by a clash between two opposing worldviews" represented by a humanistic left and a normative right [14]. In this conflict between the humanistic and the normative, the left accuses the right of defending the established system that keeps the oppressed suffering to increase economic, social and political equality, while the right defends the system to preserve tradition and their privileged status [14].

From these definitions, we understand an information war as a strategy of a higher political occurrence (political campaigns, elections, policy and decision making) that uses different methods to achieve its political goals to manipulate certain sectors of society. An ideological war is waged by the elites with resources to create and spread ideologies. It uses ideological consistency as a method to create extremists and gain political goals. The information war is a strategy of the ideological war, but the latter is not a hybrid war as it includes confrontations, especially between nations, in other fields such as the financial system, among others. The ideological war has two sides: 1) information it focuses on the spread of any type of information online and offline, including propaganda and fake news, but also printed and video material; and 2) activism - it is the physical confrontation on the streets, podiums and forums online and offline to support the ideological information war. The ongoing confrontation between American fascists and antifascists exemplifies this ideological war in its two sides.

\section{Artificial Ideologies: Fascism and Antifascism}

O. G. Derevyanko claims that fascism is an artificial ideology of political and legal thinking that considers race (ethnicity) to be the origin of the State; it is totalitarian and corporativist as it aims at the State led by one all-powerful party or racial elite; it is intolerant of, and discriminates against, the other (states, nations, ethnic groups); it uses violence to terrorize the political opposition and aims to militarize society and solve all problems through war [15]. Fascism is a chauvinist, nationalist, racist, imperialist, and State-absolutist (total control of the individuals' lives) ideology [15, p. 43-53]. This artificial ideology is one of the variants of the radical right thinking that emerged at the turn of the 20th century, of which the Italian and German versions are the most known [16, p. 78]; however, the American version has gained popularity since 2015. For Ju. A. Koshkarova, fascism is a reactionary imperialistic ideology of the bourgeoisie aimed at securing the growth of state monopoly capitalism [16, p. 78]. N. A. Khlystova considers fascism to be born out of a systemic crisis of this capitalism, in which the bourgeoisie looks to reaccommodate its forces with other dominant oppressive actors to avoid losing control of the exploited masses after having given them certain social concessions to avoid a full socialist revolution [17, p. 110]. For Italian fascism, the State creates the nation; for German fascism, the State is the only means to preserve the ethno-nation [15, p. 49]; for American fascism, it is the racially superior people that creates the State that is then used to validate and guarantee the supremacy of the racial elite and oligarchies. American fascism sees left-wing parties and progressive policies as a Marxist existential threat. It includes elements of religious extremism (superiority of Protestant Christianity) and distrusts political elites that do not share its ideological consistency. American fascism proposes the theory of a Marxist deep State puppet of the Chinese Communist Party, cooperating with Big Pharma and Big Tech corporations to achieve total control of the population. American fascism is anti-egalitarian, anti-communist, antiliberalist, nationalist and authoritarian with (so far) Donald Trump as a cult figure.

Antifascism is a movement that emerged in Western Europe as a response to the establishment of Fascist regimes in the early 20th century. In 1935, the Comintern decided to include it as part of the communist ideology and join forces with other groups like Catholics, Socialists and Anarchists in the fight against fascism under MarxismLeninism [16, p. 79]. Antifascism is a social movement aimed at fighting the spread and normalization of the ideology of fascism in the world [16, p. 79]. As an international movement, it has no sponsors or directors; nor does it have central political figures. N. A. Khlystova claims that fascism emerged as a reactionary ideology to the Socialist Russian revolution, which is logical as per the monopolistic state capitalism character previously described; thus, antifascism is the following response to contain that antagonistic artificial ideology against the socialist ideology [17, p. 110]. American media and politicians have wrongly named the antifascist movement as "Antifa", a derivative of the German Communistsponsored group Antifascist Action that fought Hitlerian fascism before World War II [18, p. 125]. Some academics have followed this path and studied American Antifascists as some type of independent "shock troop" of the left that exists in such a way only in the U.S., sidestepping years 
of history of similar activities and tactics in Europe in the fight against street fascists ${ }^{2}$. Calling Antifascists "Antifa" has created a perception among Americans that antifascists are grouped in one single entity like al-Qaeda or Daesh (Arabic name of the so called "Islamic State", a terrorist organization banned in the Russian Federation).

American antifascism is an oppositional movement of ideologies ready to use violence to protect people against the violence applied by American fascists towards nonwhites, Muslims, Jews, women, LGBTQ+ people, immigrants and other traditionally oppressed groups in American culture. They are active on social media like Twitter and Instagram, where they use doxxing as a method to expose fascists [18, p. 126, 127]. After the storming of the Capitol at DC on January 6th, 2021, the group Identify Homegrown Terrorists was created on Instagram to help identify and publicly expose individuals who broke into the Capitol, get them fired from work, affect their businesses and let them be harassed by antifascists and other citizens online. The most relevant point to highlight is that American antifascists are not looking to start a socialist revolution; their intention is to stop the advance of American fascists (including the police and politicians) into politics and their violence against others [18, p. 129].

American politicians, including former president D. Trump, have tried to designate the Antifa movement a terrorist organization [18, p. 123], which is inaccurate by definition since Antifa is not an organization or ideology, it is a movement made up of different groups and different ideologies with the aim of stopping the advance of the ideology of fascism. Moreover, if antifascism is perceived as a terrorist threat to American politicians, it only demonstrates their support for the ideology that antifascists are fighting against, rendering these politicians supporters of fascism. This criminalization of antifascism responds to decades of ideological consistency created by the government that managed to portray socialism as evil perpetually linked to Soviet Communism of the Cold War, then to Castro's Cuba and Chavez's Venezuela, and today to the Chinese Communist Party.

N. A. Khlystova has elaborated on the ideological war between fascism and antifascism in Europe in the 20th century, where she presents German, Italian and Spanish fascism as a reaction of the bourgeoisie to the advance of socialism and a strategy of these elites to retain power [17]. This ideological war was more economic and of classes as it was a war against fascist imperialism and its exploitation of workers by this bourgeoisie that felt threatened by progressive socialism $[17$, p. 114]. Other researchers have elaborated on this line of economist-class ideological war between the capitalist conservatism and the international systems and institutions and their strategies used to stop growth of the exploited masses [19, p. 25-32].

Today, American fascists are reactionaries against demands for racial justice and against police brutality, increase of immigration from non-European countries, empowerment of ethnic minorities and women in political spaces, and demands for recognition of transgender identities, among others. J. Fonte writes about this ideological war too, which he refers to as an "ideological Civil war" between liberal democracy and transnational progressivism, considering the latter an ideology threatening the American way of democracy [20]. To J. Fonte, transnational progressivism wants to build communitarian societies, sees a binary world of oppressors and victims, seeks social justice by representation of minorities based on their percentage among the total population regardless of their capabilities, aims at changing accepted identities and establishing a global international government that erodes American sovereignty [20]. To J. Fonte, liberal democracy means "individual rights, democratic representation (with some form of majority rule) and national citizenship" [20, p. 451], the values that defend American fascists that, at the same time, accuse liberal progressives of promoting communism and sabotage of American democracy. He claims that this ideological war between what he considers liberal democracy (the good side) and international progressivism (evil socialism) is promoted from within American society through failed activism for human rights that request help from external international organizations to bring the US to commit to agreements that contradict its constitution to eventually lose sovereignty to a global government. This interpretation of the ideological war is exactly what American fascist groups claim is taking place and is the reason they must be ready to act through the use of information and active means against these "transnational progressives" or, as presented in this work, antifascists.

Those individuals who have consumed the propaganda of this information war will be ideologically consistent to defend the Truth they have formed, whether it is of fascists or antifascists. Although antifascism is a needed response to fascism, it is also important to note that violent antifascism can be extreme and destructive for those individuals who do not take part in the confrontation. The ideologies of fascism and antifascist movement own different Truths that contradict each other.

\section{The Proud Boys and Atlanta Antifascists}

The Proud Boys is a violent right-wing anti-left movement and militia-like group of young men who gather to protest or counter-protest what they consider are Marxist and Antifa demonstrations ${ }^{3}$. They are especially active in the states

\footnotetext{
${ }^{2}$ Speckhard A., Molly E. Perspective: why branding Antifa a terror group is a diversion. Homeland Security Today. 2 Jun 2020. Available at: https://www.hstoday. us/subject-matter-areas/counterterrorism/perspective-why-branding-antifa-a-terror-group-is-a-diversion/ (accessed 10 Dec 2020).

${ }^{3}$ Stall H., Kishi R., Raleigh C. Militias in the ACLED dataset. Standing by: right-wing militia groups \& the US election. ACLED, $2020,7-17$.
} 
of Pennsylvania, Wisconsin, Oregon and North Carolina, where they have joined other groups, such as the Three Percenters, Patriot Prayer, Boogaloo Bois, QAnon and the Sons of Liberty; however, the Proud Boys are very mobile in their travels across the country ${ }^{4}$. The founder of the group is Gavin McInnes but the current leader is Enrique Tarrio, an American of Afro-Cuban ancestry whose political ultra conservative ideology was most likely influenced by the general anti-communist attitude of Cuban émigrés living in Florida. On their Telegram account Proud Boys ${ }^{5}$, E. Tarrio is constantly mentioned by the moderator to justify the group is not white supremacist, as E. Tarrio is mestizo. The group has 35,972 followers as of January 2021 and its motto is "I am a proud western chauvinist who refuses to apologize for creating the modern world". This motto is the phrase that aspirants must quote to be initiated into the group. It reflects the character of its members who consider that white men are currently obliged to apologize for the historical oppression of minorities and women in the US, something they believe to be promoted by the communist left. On the profile, they also share links to their Parler and Gab accounts, social media networks where other far-right extremists share content after Twitter took more aggressive measures to counter extremism.

On their Telegram account, the Proud Boys usually post memes, screenshots from Twitter comments and comments by individual actors. After the November election, they would constantly make posts in support of D. Trump's claim that the election was rigged, as well as posts of the motto "Stop the Steal" that his supporters used to fight the democratic and deep-State elites that supposedly hate D. Trump. The Proud Boys would also make posts against the COVID-19 vaccine, feminism and Islam. They accused Bill Gates, Jeff Bezos, Mark Zuckerberg, and Twitter of interfering in the election. On January 6th, they made two posts: 1 ) a video of an individual advising other Proud Boys not to go to DC to support D. Trump in preventing the "steal", 2) a gif commenting "Politicians that have been bullying the American people are afraid that they might have to face the citizens they have been fucking over for decades? I wonder why" - clearly referring to the people and activists who had already gathered at the Capitol to illegally break in on that day.

On January 7 th, they made a three-paragraph post with a photo of the extremists who broke into the Capitol claiming "the left \& the media have been excusing the actions of BLM (Black Lives Matter) \& Antifa all year. Burning buildings, looting, destroying private property, attacking courthouses, violence in the streets, murder, etc. They also never waited for the system to work before they rioted". In this post, they claim that the left used this type of intimidation to get their way against police brutality (though police brutality against black citizens continues to be reported). They end this post by saying "It looks like the right have also learned this lesson. Hope you are satisfied". With this they justify the actions of far-right extremists by claiming the left were also violent throughout the summer of 2020. On January 11 th, after Twitter blocked D. Trump and purged other farright ideologues and users from the platform, the moderator posted an article from Thegatewaypundit entitled "Our Motherf*cking Streets! Antifa Terrorists March Through NYC in Riot Gear". Later that day, they posted a photo of a woman - presumably, Ashli Babbitt (the woman shot and killed inside the Capitol) - holding a black banner with the motto "F*ck Antifa" written in white letters. On the same day, they posted an image of the Twitter bird logo in red with the Communist sickle and hammer and the yellow five stars of the Chinese flag in a black background with the message "Dump twitter. Dump facebook. Dump apple. Dump google. Dump amazon". This was a response to the purge of farright ideologues and users blocking D. Trump, removing the Parler app from the Apple store and not hosting Parler in the servers of Amazon.

On January 12th, the administrator made a post of a screenshot from Twitter to show how Twitter supposedly allowed footballer Colin Kaepernick to incite violence on May 2020 after the murder of George Floyd. The administrator claims that this influenced the BLM protests. They posted a video made by the Caldron Pool showing different interviews of politicians, especially of Nancy Pelosi and Kamala Harris, with media such as MSNBC and CNN, where they supposedly call for continuing violence of BLM on the streets as demonstrations against D. Trump. The administrator wrote, "The Left insights violence for the last four years. But apparently left-wing violence is ok". On that day, the administrator reposted a message by Weaponized Opinions Podcast (another rightwing channel of American content with 2,115 subscribers): "The Left: The Sexualization of Children. The Normalization of Pedophilia. The Demonization of Conservatives. Encouraging the Break-Down Of The Family Unit. Pushing Socialism, Open Borders, And Globalization. But We Are Supposed To Believe Conservatives Are The Problem..."

On January 13th, the administrator posted a message by E. Tarrio calling their followers to not attend the Million Militia March planned for January 20th, claiming "We suggest none of you go to these events. We won't sit on our hands for the next four years but we can pick and choose our battles moving forward", which was rather an indicator the group was going into an existential crisis. Posts in this channel have decreased in relevance and quantity after January 20th, when Joe Biden was sworn president.

\footnotetext{
${ }^{4}$ Stall H., Kishi R., Raleigh C. Drivers and barriers of militia activity. Standing by: right-wing militia groups \& the US election. ACLED, 2020, 19-29.

${ }^{5}$ Proud Boys. Telegram. Available at: https://t.me/proudboysusa (accessed 12 Oct 2020).
} 
Atlanta Antifascists Twitter account has 21,221 readers and a total of 13,856 tweets as of the day this work was done in January 2021. Their activity is extensive in January, especially on January 6th, when they tweeted about the arrest of E. Tarrio and some news about a face-off between Salem anti-fascists and far-right sympathizers who targeted a store. During the day, they tweeted updates, videos and news of clashes in DC between the Proud Boys and BLM and antifascists, as well as how far-right demonstrators broke the barricades and rushed to the Capitol. They gave special attention to the Confederate flag being spotted inside the Capitol and made comparisons claiming that had BLM and anti-racist, anti-police brutality or any leftist demonstrators broken into the Capitol like the farright extremists did, the consequences would have been different (they would have been violently stopped by police). In some tweets and retweets, they refer to farright demonstrators as "fascists" and "white nationalists". For example, "We literally warned everyone that fascists are trying an insurrection after Trump's defeat..." tweeted by @All_Out_DC, highlighting their self-identification as antifascists and their knowledge of political theories. Another tweet on that day (by @lukeobrien) said, "Let's all never forget that billionaires Jack Dorsey and Mark Zuckerberg also made this fascist moment possible. While making money off it" (the former is the CEO and founder of Twitter and the latter is the CEO and founder of Facebook). This suggests that these administrations allowed hate speech and conspiracy theories on their platforms, especially Facebook. A critique of the technological elites is that although neither Facebook nor Twitter are ideologues, they are the tools used to spread fascist ideologies down to the masses.

After this day, they tweeted videos of a fascist militia marching to the Atlanta Capitol, others from the demonstration at DC destroying equipment from $\mathrm{CNN}$ journalists, and another video of the Proud Boys shooting pepper spray at protestors in Salem. On January 7th, they retweeted a piece of news by The Guardian entitled "White supremacists and militias have infiltrated police across the US, report says" from August 2020. This is a claim made by American antifascists, as police have shown preference for fascist demonstrators. Some were seen letting those enter the Capitol on January 6th, while others took pictures with the criminals. On another occasion, some police officers thanked the vigilante white supremacist Kyle Rittenhouse in Antioch for shooting and killing two demonstrators at a rally against police brutality in the summer. From January 7 th on, they started doxxing fascists and far-right demonstrators who took place in the storming of the DC Capitol, getting them exposed (sometimes fired from their jobs) and cooperating with the FBI. On January 11th, they retweeted a message from United Against Racism and Fascism NYC (@UARFNYC) that read "Today NYC had an anti-fascist victory - MAGA and the Proud Boys didn't show up *because* we mobilized!...", achieving one of the aims of the antifascism movement. Atlanta Antifascists have also identified members of the white nationalist militia, the Three Percenters who attacked antiracist / anti-fascist unarmed demonstrators in Georgia in December 2020.

On January 14th, Atlanta Antifascists released a statement explaining the mobilizations of different far-right and fascist groups in Atlanta on January 16th-20th. In particular, they claimed, "...we recommend a strong presence to counter far-right activity... There are at least three factions involved on the 17th: "Booger", MAGA / Qanon, and law enforcement..." On January 20th, the day J. Biden took office as the 46th president, the Atlanta Antifascists tweeted, "Presidents have changed, the fight continues". Unlike the Proud Boys, Atlanta Antifascists have not ceased to post daily, reporting on activities of American fascists, far-right politicians who believe in conspiracy theories of QAnon and actions by European antifascists, among other things.

A considerable point to take into account about this ideological war between American fascists and antifascists is that the former are more actively engaged in militia activities for their vision on the right to possess weapons. There are antifascist militias like the NFAC (Not F*cking Around Coalition) made up of only black members with the aim of protecting black Americans from armed white supremacist violence, and the Redneck Revolt, which is anti-white supremacy and anti-capitalist and is made up of predominantly (but not exclusively) working class whites. It is the fascist militias that are usually and disproportionally involved in violence on the streets and murder of antifascist protestors ${ }^{6}$.

\section{Conclusion}

The ideologies of fascism and antifascism do coexist but in violence, as every time their sympathizers meet at the same place, there are confrontations. During D. Trump's presidency, the Proud Boys, of fascist ideology, felt empowered during the four years after their creation, and of that American administration that was perceived as the enabler of the ethnonationalist, anti-immigrant, anti-LGBTQ+, and anti-Islam ideology. The antifascist movement, on the contrary, had a complicated time during these very four years as they were perceived as the terrorist enemy by $\mathrm{D}$. Trump's administration, evidencing that in the American regime these two ideologies could not be tolerated at the same time. For the new administration of J. Biden, it is the fascist ideology of the Proud Boys that is not tolerable. In his inaugural speech, J. Biden denounced their ideology saying that they should be considered domestic terrorism. From their Telegram channel, we can conclude

\footnotetext{
${ }^{6}$ Kishi R., Stall H., Jones S. Potential trajectories. The future of 'Stop the Steal': Post-election trajectories for right-wing mobilization in the US. ACLED, $2020,15-19$.
} 
that the Proud Boys are going through a reorganization as D. Trump, their cult figure, is no longer in charge; neither does he seem interested in leading an ideological movement they would expect him to. It is likely that fascist groups and militias will go back to less public channels unless another high-ranking politician takes power again.

Antifascists will continue to operate online during J. Biden's administration, exposing and doxxing fascist politicians, ideologues and activists. They cannot be expected to go back to the streets en masse unless there are situations pushing them outside, for example, if police brutality, institutional racism and misogyny come back to being part of the presidential discourse. This is not likely though, as the J. Biden administration follows the same ideological consistency of this progressive antifascist movement that got him the presidency in a probable attempt to achieve social stability and political legitimacy. This validates the instrumental ideological consistency proposed by J. Barceló as it is the masses that dictate the ideology they want the US government to follow.
Two or more different or opposing ideologies can coexist in the same society at the same time, but their social acceptance will depend on the political discourse and the ideological consistency of the elites. Since the Cold War, American elites have formed the Truth that socialism and any left-wing movement is dangerous for American sovereignty by creating an ideological consistency that values individualism to empower consumption benefitting these very same elites. In the American political system, the elites use the State to benefit and protect their interests, being then a state monopoly capitalist system of the bourgeoisie. This has allowed the emergence of the ideology of European ethnonationalist supremacy that sees the non-European as foreign and the international as an enemy. Any type of xenophobia and racial hatred is capable of creating the conditions for the emergence of fascism, so the D. Trump phenomenon should not be considered unexpected as this had been constructed over decades. This should serve as a case study for other States that allow oligarchs to gradually meddle into the political system and decision making.

\section{References}

1. Denchev K. Far-right wave in Europe: 1990s and the beginning of the 21st century. Novaia i noveishaia istoriia, 2008, (5): 68-83. (In Russ.)

2. Valiakhmetov A. I. Media as a factor of spreading the ideologies of extremism and terrorism. Tinchurin readings: Proc. XIV Intern. Youth Sci. Conf., Kazan, 23-26 Apr Kazan, 2019, vol. 3, 340-343. (In Russ.)

3. Nyst M. Social media and counterterrorism. Counterterrorism. Yearbook-2019, eds. Kifr I., Grice G. Barton: ASPI, 2019, 115-123.

4. Pantucci R., Ong K. Persistence of right-wing extremism and terrorism in the West. Counter Terrorist Trends and Analyses, 2021, 13(1): 118-126.

5. Cohen-Almagor R. Taking North American white supremacist groups seriously: the scope and challenge of hate speech on the Internet. International Journal for Crime, Justice and Social Democracy, 2018, 7(2): 38-57. DOI: 10.5204/ijcjsd. v7i2.517

6. Darius P., Stephany F. How the Far-right polarises Twitter: 'highjacking' hashtags in times of COVID-19. SocArXiv, 2020. DOI: $10.31235 /$ osf.io/n6f3r

7. Akerlund M. The importance of influential users in (re)producing Swedish far-right discourse on Twitter. European Journal of Communication, 2020, 35(6): 613-628. DOI: 10.1177/0267323120940909

8. Rivas-de-Roca R., Garcia-Gordillo M., Bezunartea-Valencia O. The far-right's influence on Twitter during the 2018 Andalusian elections: an approach through political leaders. Comunication \& Society, 2020, 33(2): 227-242. DOI: $10.15581 / 003.33 .2 .227-242$

9. Gonzalez Cedillo J. I. From ideology to hate speech and the problem of Euro-American white supremacist extremism. Vestnik Permskogo universiteta. Politoligia, 2020, 14(4): 5-13. DOI: 10.17072/2218-1067-2020-4-5-13

10. Barcelo J. Ideological consistency, political information and elite-mass congruence. Social Science Quarterly, 2017, 98(1): 144-161. DOI: $10.1111 /$ ssqu. 12282

11. Kunakova L. N. Information warfare as an object of scientific analysis (concept and main characteristics). Almanakh sovremennoi nauki i obrazovaniia, 2012, (6): 93-96. (In Russ.)

12. Abdyraeva $\mathrm{C}$. The use of cyberspace in the context of hybrid warfare: means, challenges and trends. Wien: Österreichisches Institut für Internationale Politik, 2020, 36.

13. Yaroshenko M. P. Using the ideology of extremism as a tool in conducting a hybrid war. Obzor.NTsPTI, 2018, (4): 52-58. (In Russ.)

14. Nilsson A., Jost J. T. Rediscovering Tomkins' polarity theory: humanism, normativism, and the psychological basis of left-right ideological conflict in the U.S. and Sweden. PLoS ONE, 2020, 15(7). DOI: 10.1371/journal.pone.0236627

15. Derevyanko O. G. Characteristic of fascism as political and legal doctrine. Vestnik Mezhdunarodnogo iuridicheskogo instituta, 2016, (2): 42-59. (In Russ.) 
16. Koshkarova Ju. A. Fascism as a kind of right wing radicalism. Vestnik Akademii ekonomicheskoi bezopasnosti MVD Rossii, 2015, (6): 78-80. (In Russ.)

17. Khlystova N. A. Historic clash of ideologies. Vestnik Tomskogo gosudarstvennogo universiteta. Istoriya, 2011, (1): 110-116. (In Russ.)

18. Copsey N., Merrill S. Violence and restraint within Antifa: a view from the United States. Perspectives on Terrorism, 2020, 14(6): 122-138.

19. Gomez Walteros J. A., Rodriguez A. B., Banda Mora A. P. El extremismo conservador y la nueva fase globalizada de acumulación de capital. Clivajes. Revista de Ciencias Sociales, 2019, (11): 23-40. DOI: 10.25009/clivajes-rcs.v0i11.2559

20. Fonte J. Liberal Democracy vs. Transnational Progressivism: The Ideological War Within the West. Orbis, 2002, 46(3): 449-467. DOI: 10.1016/S0030-4387(02)00126-6

оригинамьная статья

УАК 323.14

\title{
Идеологическая последовательность и идеологическая война: американский фашизм против антифашизма, январь 2021 г.
}

\author{
Хоем Иван Гонсамес СеАимло \\ Санкт-Петербургский государственный университет, Россия, г. Санкт-Петербург \\ ivangzz.ced@gmail.com \\ http://orcid.org/0000-0001-8040-749X
}

Поступика в реАакцию 04.02.2021. Принята в печать 05.03.2021.

\begin{abstract}
Аннотация: Анализируются идеологическая война межАу американскими фашистами и антифашистами и связь существования идеологической последовательности масс с возникновением конфмикта такого типа. Отражение и обсуждение штурма Капитолия США фашистами в январе 2021 года, а также деятельность этих групп и антифашистов в социальных сетях служат предметом анализа этой идеологической войны. Цель - преАставить Аитературу и Аать анализ того, каким образом государства могут подАерживать экстремистские идеологии на основе собственной идеологической последовательности. Методом, используемым Аля разоблачения идеологической войны, избран контент-анализ социальных сетей, в которых «Гордые парни» (Proud Boys) и антифашисты из Атланты сообщают о своей деятельности в реальном мире. Результаты показывают, что Аве конкурирующие идеологии не могут мирно сосуществовать на оАной и той же территории и в оАно время. ГосуАарство и элиты выражают согласие на прекращение конфронтации. Аанная работа может быть полезна Аля ученых, политиков и студентов, работающих наА проблемой фашистских и экстремистских иАеологий и разработки путей борьбы с ними с обращением к инструментам их реализации.

Ключевые слова: американский фашизм, антифашизм, белый супремасизм, идеология, экстремизм
\end{abstract}

Цитирование: Gonzalez Cedillo J. I. Ideological Consistency and Ideological War: American Fascism vs Antifascism January 2021 // Вестник Кемеровского государственного университета. Серия: Политические, социологические и экономические науки. 2021. Т. 6. № 1. С. 10-18. DOI: https://doi.org/10.21603/2500-3372-2021-6-1-10-18

\section{Митература}

1. Аенчев К. «УАьтраправая волна» в Европе: 90-е годы XX - начало ХХІ века / / Новая и новейшая история. 2008 . № 5. C. $68-83$.

2. Валиахметов А. И. СМИ как фактор распространения идеологий экстремизма и терроризма // Тинчуринские чтения: мат-лы XIV Междунар. молодежной науч. конф. (Казань, 23-26 апреля, 2019) Казань, 2019. Т. 3. С. 340-343.

3. Nyst M. Social media and counterterrorism // Counterterrorism. Yearbook-2019 / eds. I. Kifr, G. Grice. Barton: ASPI, 2019. P. 115-123.

4. Pantucci R., Ong K. Persistence of right-wing extremism and terrorism in the West // Counter Terrorist Trends and Analyses. 2021. Vol. 13. Iss. 1. P. 118-126. 
5. Cohen-Almagor R. Taking North American white supremacist groups seriously: the scope and challenge of hate speech on the Internet // International Journal for Crime, Justice and Social Democracy. 2018. Vol. 7. Iss. 2. P. 38-57. DOI: 10.5204/ijcjsd.v7i2.517

6. Darius P., Stephany F. How the far-right polarises Twitter: 'highjacking' hashtags in times of COVID-19 // SocArXiv. 2020. DOI: $10.31235 /$ osf.io/n6f3r

7. Akerlund M. The importance of influential users in (re)producing Swedish far-right discourse on Twitter // European Journal of Communication. 2020. Vol. 35. Iss. 6. P. 613-628. DOI: 10.1177/0267323120940909

8. Rivas-de-Roca R., Garcia-Gordillo M.,Bezunartea-Valencia O. The far-right's influence on Twitter during the 2018 Andalusian elections: an approach through political leaders // Comunication \& Society. 2020. Vol. 33. No. 2. P. 227-242. DOI: 10.15581/003.33.2.227-242

9. Gonzalez Cedillo J. I. From ideology to hate speech and the problem of Euro-American white supremacist extremism // Вестник Пермского университета. Политология. 2020. Т. 14. № 4. С. 5-13. DOI: 10.17072/2218-1067-2020-4-5-13

10. Barcelo J. Ideological consistency, political information and elite-mass congruence // Social Science Quarterly. 2017. Vol. 98. Iss. 1. P. 144-161. DOI: $10.1111 /$ ssqu. 12282

11. Кунакова $\Lambda$. Н. Информационная война как объект научного анализа (понятие и основные характеристики информационной войны) // Альманах современной науки и образования. 2012. № 6. С. 93-96.

12. Abdyraeva $C$. The use of cyberspace in the context of hybrid warfare: means, challenges and trends. Wien: Österreichisches Institut für Internationale Politik, 2020.36 p.

13. Ярошенко М. П. Использование идеологии экстремизма как инструмента в ведении гибридной войны // Обзор. НЦПТИ. 2018. № 4. С. 52-58.

14. Nilsson A., Jost J. T. Rediscovering Tomkins' polarity theory: humanism, normativism, and the psychological basis of leftright ideological conflict in the U.S. and Sweden // PLoS ONE. 2020. Vol. 15. No. 7. DOI: 10.1371/journal.pone.0236627

15. Аеревянко О. Г. Характеристика фашизма как политико-правового учения / / Вестник Международного юридического института. 2016. № 2. С. 42-59.

16. Кошкарова Ю. А. Фашизм как разновидность правого радикализма // Вестник Академии экономической безопасности МВА России. 2015. № 6. С. 78-80.

17. ХАыстова Н. А. Историческое столкновение идеологий // Вестник Томского государственного университета. История. 2011. № 1. С. 110-116.

18. Copsey N., Merrill S. Violence and restraint within Antifa: a view from the United States // Perspectives on Terrorism. 2020. Vol. 14. № 6. P. 122-138.

19. Gomez Walteros J. A., Rodriguez A. B., Banda Mora A. P. El extremismo conservador y la nueva fase globalizada de acumulación de capital // Clivajes. Revista de Ciencias Sociales. 2019. Num. 11. P. 23-40. DOI: 10.25009/clivajes-rcs. v0i11.2559

20. Fonte J. Liberal Democracy vs. Transnational Progressivism: The Ideological War Within the West // Orbis. 2002. Vol. 46. Iss 3. P. 449-467. DOI: 10.1016/S0030-4387(02)00126-6 